\title{
PENERAPAN MEDIA “PUZPIPI" PADA MATA PEAJARAN IPS UNTUK MENINGKATKAN HASIL BELAJAR SSWA KELAS III SD MUHAMMADIYAH 5 MALANG
}

\author{
Maslikah \\ SD Muhammadiyah 5 Kota Malang \\ Email : muslikah.sdmmalang@gmail.com
}

\begin{abstract}
In social studies class III in SD Muhammadiyah Malang 5, known to students' learning outcomes averaged 6.8. While KKM desired targets for social studies that is equal to 7.5. The reality is affected by the implementation of learning less interesting. This is due to the learning process a lot to do with the lecture course by the teacher, the use of learning methods that are tedious and teachers do not use props. So based on the above description, it should be done using the medium of learning innovation "puzpipi" (puzzle - picture and picture). Therefore, the purpose of this study is to describe the application of the media "puzpipi" so as to improve student achievement in social studies class III SD Muhammadiyah Malang 5 as well as to describe the learning outcomes of students in IPS Lesson 5 Class III SD Muhammadiyah Malang after Applied Media "puzpipi" This study used a qualitative descriptive approach and type of research is Classroom Action Research (CAR). The action taken is the implementation of a media "puzpipi" to improve student learning outcomes in social studies teaching third grade students of SD Muhammadiyah Malang 5. The subjects were students of class III SD Muhammadiyah Malang 5 the number of third grade students were 14 people in the second semester of academic year 2012/2013. "Puzpipi" media usage (puzzles and picture and picture) can improve the learning outcomes of students grade III SD Muhammadiyah Malang 5. Improving student learning outcomes from the first cycle to the second cycle increased. First cycle of 61.6 and 81.9 for the second cycle. Classical completeness is also increased in the first cycle of $69.7 \%$, while in the second cycle of $81.4 \%$.
\end{abstract}

\begin{abstract}
Abstrak: Dalam mata pelajaran IPS kelas III di SD Muhammadiyah 5 Malang, diketahui hasil belajar siswa rata-ratanya 6,8. Sedangkan target KKM yang diinginkan untuk pelajaran IPS yaitu sebesar 7,5. Kenyataan tersebut dipengaruhi oleh kurang menariknya pelaksanaan pembelajaran. Hal ini disebabkan dalam proses pembelajaran banyak dilakukan dengan ceramah saja oleh guru, penggunaan metode pembelajaran yang monoton dan guru tidak menggunakan alat peraga. Maka berdasarkan uraian di atas, perlu dilakukan inovasi pembelajaran dengan menggunakan media "Puzpipi" (puzzle-picture and picture). Oleh karena itu, tujuan penelitian ini adalah untuk mendeskripsikan penerapan media "puzpipi" sehingga dapat meningkatkan prestasi belajar siswa pada pelajaran IPS kelas III SD Muhammadiyah 5 Malang serta untuk mendeskripsikan hasil belajar siswa pada Pelajaran IPS Kelas III SD Muhammadiyah 5 Malang setelah diterapkan Media "Puzpipi". Penelitian ini menggunakan pendekatan deskriptif kualitatif dan jenis penelitian berupa Penelitian Tindakan Kelas (PTK). Tindakan yang dilakukan adalah penerapan media "puzpipi" untuk meningkatkan hasil belajar siswa pada pembelajaran IPS siswa kelas III SD Muhammadiyah 5 Malang. Subjek penelitian ini adalah siswa kelas III SD Muhammadiyah 5 Malang dengan jumlah siswa kelas III adalah 14 orang pada semester II tahun pelajaran 2012/2013. Penggunaan media puzpipi (puzzle dan picture and picture) dapat meningkatkan hasil belajar siswa kelas III SD Muhammadiyah 5 Malang. Peningkatan hasil belajar siswa dari siklus I ke siklus II meningkat. Siklus I sebesar 61,6 dan siklus II sebesar 81,9. Ketuntasan klasikal juga mengalami peningkatan yaitu pada siklus I sebesar $69,7 \%$ sedangkan pada siklus II sebesar $81,4 \%$.
\end{abstract}

Kata Kunci: "Puzpipi”, hasil belajar, IPS 
Ilmu Pengetahuan Sosial (IPS) merupakan nama mata pelajaran ditingkat sekolah atau nama program studi di perguruan tinggi. Mata pelajaran ini identik dengan istilah "social studies" dalam kurikulum persekolahan di negara lain, khususnya di negara-negara barat seperti Australia dan Amerika Serikat.

Tujuan pendidikan IPS dikembangkan atas dasar pemikiran bahwa pendidikan IPS merupakan suatu disiplin ilmu. Oleh karena itu pendidikan IPS harus mengacu pada tujuan Pendidikan Nasional. Dengan demikian tujuan pendidikan IPS adalah mengembangkan kemampuan peserta didik dalam menguasai disiplin ilmu-ilmu sosial untuk mencapai tujuan pendidikan yang lelebih tinggi.

Ada tiga aspek yang harus dipenuhi dalam pengembangan pendidikan IPS, yaitu aspek intelektual, kehidupan sosial, dan kehidupan individual. Pengembangan kemampuan intelektual lebih didasarkan pada pengembangan disiplin ilmu itu sendiri serta pengembangan akademik dan thinking skill. Tujuan intelektual berupaya untuk mengembangkan kemampuan siswa dalam memahami disiplin ilmu sosial, kemampuan berpikir, kemampuan prosesual dalam mencari informasi dan mengkomunikasikan hasil temuan. Pengembangan kehidupan sosial berkaitan dengan pengembangan kemampuan dan tanggung jawab siswa sebagai anggota masyarakat. Tujuan ini mengembangkan kemampuan seperti berkomunikasi, rasa tanggung jawab sebagai warga negara dan warga dunia, kemampuan berpartisipasi dalam kegiatan-kegiatan kemasyarakatan dan bangsa. Termasuk dalam tujuan ini adalah pengembangan pemahaman dan sikap positif siswa terhadap nilai, norma dan moral yang berlaku dalam masyarakat. (Sundawa, 2006)

Berdasarkan uraian di atas, untuk mencapai proses pembelajaran IPS yang mampu melatih keterampilan sosial, akademik, dan berpikir siswa, maka di- perlukan suatu inovasi pembelajaran. Salah satunya melalui penggunaan alat peraga. Menurut Pujiati (2004) ada beberapa fungsi alat peraga dalam proses pembelajaran, diantaranya supaya anak-anak lebih besar minatnya, supaya anak-anak dibantu pemahamannya sehingga lebih mengerti dan lebih besar daya ingatnya, supaya anakanak dapat melihat hubungan antara ilmu yang dipelajarinya dengan alam sekitar dan masyarakat. Dan dengan alat peraga dapat menumbuhkan kegairahan belajar serta dapat meningkatkan aktivitas dan kreatifitas, efisiensi waktu dan efisiensi motivasi dalam proses belajar mengajar. Dengan demikian proses pembelajaran tersebut bermakna bagi siswa karena mampu melatih keterampilan sosial, akademik, berpikir siswa.

Proses pembelajaran yang bermakna bagi siswa diharapkan mampu melakukan perubahan pada tingkah laku siswa. Perubahan yang demikian menurut Nana Sujana (1995) disebut dengan prestasi, yang merupakan perubahan tingkah laku sebagai hasil belajar dalam pengertian yang luas mencakup bidang kognitif, afektif dan psikomotorik.

Dalam mata pelajaran IPS kelas III di SD Muhammadiyah 5 Malang, diketahui hasil belajar siswa rata-ratanya 6,8. Sedangkan target KKM yang diinginkan untuk pelajaran IPS yaitu sebesar 7,5. Kenyataan tersebut dipengaruhi oleh kurang menariknya pelaksanaan pembelajaran. Hal ini disebabkan dalam proses pembelajaran banyak dilakukan dengan ceramah saja oleh guru, penggunaan metode pembelajaran yang monoton dan guru tidak menggunakan alat peraga. Maka berdasarkan uraian di atas, perlu dilakukan inovasi pembelajaran dengan menggunakan media "Puzpipi" (puzzle-picture and picture). Media "Puzpi$p i$ " yang direncanakan oleh peneliti diharapkan akan dapat meningkatkan hasil belajar siswa, karena dengan media "Puzpipi" ini siswa dituntut untuk aktif dan pembelajaran akan lebih menyenangkan. Maka pe- 
neliti akan melakukan penelitian yang lebih mendalam dengan judul" Penerapan Media "Puzpipi" untuk Meningkatkan Hasil Belajar Siswa pada Pelajaran IPS Kelas III SD Muhammadiyah 5 Malang”.

\section{Metode}

Penelitian ini dirancang dengan menggunakan pendekatan deskriptif kualitatif dan jenis penelitian berupa Penelitian Tindakan Kelas (PTK). Menurut Arikunto (2006: 13) menyebutkan bahwa Penelitian Tindakan Kelas (PTK) adalah bentuk kajian kelas yang bersifat reflektif oleh pelaku tindakan (guru atau pendidik) untuk meningkatkan kemantapan rasional dalam melaksanakan tugas, memperdalam pemahaman terhadap tindakan-tindakan yang dilakukannya, dan memperbaiki praktik-praktik pembelajaran yang dilakukan (guru atau pendiidik). Tindakan yang dilakukan adalah penerapan media "puzpipi" untuk meningkatkan hasil belajar siswa pada pembelajaran IPS siswa kelas III SD Muhammadiyah 5 Malang.

Dalam penelitian ini terdapat dua siklus. Siklus I dengan dua kali pertemuan dan Siklus II dengan dua kali pertemuan. Alokasi waktu satu jam pelajaran adalah 35 menit. Penelitian Tindakan Kelas (PTK) digambarkan sebagai suatu proses yang dinamis meliputi aspek perencanaan, tindakan, observasi, dan refleksi yang merupakan langkah berurutan dalam satu siklus yang akan berhubungan dengan siklus berikutnya. Model penelitian ini adalah model PTK guru sebagai peneliti yang dikembangkan oleh Kemmis dan Taggart (dalam Arikunto, 2006:132). Subjek penelitian ini adalah siswa kelas III SD Muhammadiyah 5 Malang dengan jumlah siswa kelas III adalah 14 orang pada semester II tahun pelajaran 2012/2013.

Tabel 3.1 Tabel Aspek łạng Diteliti, Data, Sumber Data, Telamik Pengumpuhn Data

\begin{tabular}{|c|c|c|c|}
\hline No. & Aspek yang Dittelitt & Sumber Data & Teknnik Pengumpulan Data \\
\hline 1. & $\begin{array}{l}\text { Pelaksandart } \\
\text { pengzunaun madia } \\
\text { "puzpipi" }\end{array}$ & $\begin{array}{l}\text { - Wawancara } \\
\text { - Rpp } \\
\text { - Media "puzpipi" } \\
\text { - Krgjatan siswa }\end{array}$ & $\begin{array}{l}\text { - Pedcman wawancar } \\
\text { - Lembar pengamatan } \\
\text { - LK3 } \\
\text { - Dnkumentasi (fnto) }\end{array}$ \\
\hline 2. & $\begin{array}{l}\text { Hesil piestesi bulajal } \\
\text { siswn }\end{array}$ & Lemlar Te: & TEs \\
\hline
\end{tabular}

Pengumpulan data yang dilakukan peneliti adalah sebagai berikut:

Observasi yang digunakan adalah observasi langsung yang berarti pengamatan langsung oleh peneliti dengan melihat dan mengamati sendiri, mencatat perilaku siswa, dan kejadian di kelas berkaitan dengan tindakan yang diberikan. Observasi ini bertujuan unstuk mengetahui apakah rencana pembelajaran yang telah disusun sudah dilaksanakan dengan baik.

Wawancara ini dilakukan kepada observer dan guru lain yang mengajar di kelas III serta kepada murid yaitu tanya jawab mengenai pembelajaran di kelas seperti model dan media yang sudah dan belum digunakan oleh guru, hasil belajar yang diperoleh siswa, karakteristik siswa kelas III SD Muhammadiyah 5 Malang.

Dokumentasi yang digunakan dalam penelitian ini berupa dokumentasi foto. Data yang dikumpulkan dengan teknik ini berupa foto kegiatan selama proses pembelajaran berlangsung. Peristiwa yang didokumentasikan diusahakan dapat mewakili setiap kegiatan dalam pembelajaran.

Tes merupakan alat ukur yang digunakan sebagai alat untuk menguji kemampuan siswa dalam memahami pelajaran yang disampaikan. Pelaksanaan tes diberikan diakhir setiap pertemuan. Tes yang digunakan adalah soal evaluasi berdasarkan materi. Tes ini digunakan untuk peningkatan hasil belajar belajar siswa setelah dilakukan tindakan. Hasil dari siklus I dapat dijadikan sebagai acuan untuk bahan refleksi pada siklus selanjutnya.

\section{Analisis Data, Evaluasi dan Refleksi}

Analisis data dilakukan sejak penelitian dimulai, dikembangkan selama proses refleksi sampai proses penyusunan laporan. Data yang telah terkumpul akan dianalisis secara deskriptif kualitatif. 
Data kualitatif berupa catatan lapangan, dokumen foto, wawancara, dan hasil tes melalui media pembelajaran "puzpipi" yang dilakukan pada tiap akhir siklus berupa skor yang akan dideskripsikan.

Keberhasilan tindakan pada penelitian ini dapat dikeketahui dari rata-rata kelas dan hasil pengamatan aktifitas siswa.

Untuk mengetahui hasil belajar, maka pada penelitian ini rata-rata skor hasil belajar siswa pada siklus I akan dibandingkan dengan rata-rata skor hasil belajar pada siklus II.

Analisis untuk mengetahui peningkatan hasil belajar siswa yang ditentukan dengan ketuntatasan belajar siswa secara individual dan secara klasikal. Kriteria peningkatan penguasaan minimal dengan hasil belajar yang digunakan dalam penelitian ini adalah:

1. Individual, dianggap telah "tuntas belajar" apabila daya serap mencapai $75 \%$

2. Klasikal, dianggap telah "tuntas belajar" apabila mencapai $85 \%$ dari jumlah yang mencapai daya serap $75 \%$

Apabila kedua kriteria di atas sudah terpenuhi maka siklus dihentikan.

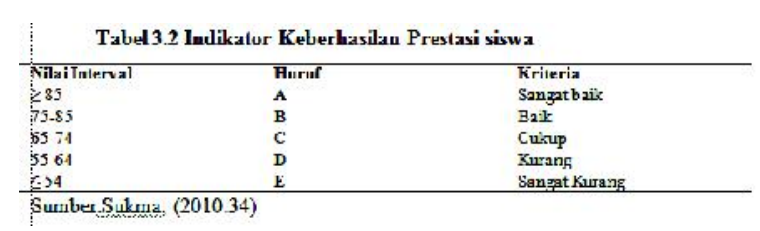

Data aktifitas siswa diperoleh dari lembar observasi dan catatan lapangan dalam penelitian. Lembar observasi berisi jabaran aktivitas-aktivitas yang dilakukan siswa selama pembelajaran berlangsung.

\section{Hasil dan Pembahasan}

Sebelum pelaksanaan penelitian, terlebih dahulu dilakukan observasi awal di kelas III SD Muhammadiyah 5 Malang sekitar bulan Januari 2013. Selain melakukan observasi, peneliti juga melakukan wawancara dengan guru lain yang juga mengajar di kelas III mengenai strategi pembelajaran yang sering digunakan dan kendala-kendala yang dialami dalam melakukan pengajaran di kelas. Diperoleh gambaran kondisi siswa saat pembelajaran berlangsung sebagai berikut: (1) Ketuntasan belajar siswa masih rendah yaitu hanya $20 \%$ saja siswa yang dinyatakan tuntas dalam belajar $(\mathrm{KKM}=75)$. (2) Pembelajaran cenderung berpusat pada guru dimana siswa kurang berkesempatan untuk mengembangkan kreativitas dan belum terlibat langsung dalam pembelajaran. (3) siswa masih banyak yang berbicara dengan temannya saat pembelajaran, siswa kurang bersemangat dan terlihat bosan dalam belajar.

\section{Siklus I}

Sebelum pelaksanaan tindakan disusun rencana pembelajaran. Perencanaan yang dilakukan adalah: (1) menyusun Rencana Pelaksanaan Pembelajaran (RPP) pada Standar Kompetensi 2. Memahami jenis pekerjaan dan penggunaan uang, Kompetensi Dasar 2.3 Memahami kegiatan jual beli di lingkungan rumah dan sekolah. (2) menyusun Lembar Kegiatan Siswa (LKS). (3) menyiapkan soal evaluasi. (4) menyiapkan media puzpipi. (5) membagi kelas menjadi 5 kelompok secara heterogen, setiap kelompok terdiri dari 2-3 siswa. (6) menyiapkan instrumen observasi aktivitas siswa dan guru.

Pelaksanaan tindakan siklus I dilaksanakan pada hari Senin tanggal 11 Pebruari 2013 dengan alokasi waktu $3 \times 35$ menit $(1-$ 05 menit). Dalam penelitian ini peneliti dan observer berkolaborasi, dan peneliti bertindak sebagai guru yang memberikan pengajaran di kelas dan dua orang teman sejawat sebagai observer.

Pelaksanaan pembelajaran berlangsung di kelas III SD Muhammadiyah 5 Malang pada Standar Kompetensi 2. Memahami jenis pekerjaan dan penggunaan uang, Kompetensi Dasar 2.3 Memahami kegiatan 
jual beli di lingkungan rumah dan sekolah. Adapun kegiatan belajar mengajar pada siklus I adalah sebagai berikut:

Pertemuan pada siklus I diadakan tanggal 11 Pebruari 2013 hari Senin jam ke 13. Jam ke 1-3 sangat kondisional sekali karena para siswa masih fresh sehingga bisa mengikuti pembelajaran dengan baik sesuai dengan tujuan yang diharapkan oleh peneliti.

Berdasarkan catatan lapangan pada siklus I yang dilaksanakan, diketahui bahwa terdapat 1 siswa yang tidak masuk karena sakit Situasi saat pembelajaran berlangsung sudah cukup baik dan kondusif dan keaktifan siswapun sudah terlihat, akan tetapi karena posisi berdiri guru yang masih kurang menguasai kelas, maka siswa yang sebenarnya ingin bertanya atau berpendapat kurang terakomodasi. Hal ini akan menjadi catatan perbaikan pada siklus berikutnya.

Hasil kegiatan pada siklus I diperoleh data tentang hasil belajar siswa. Data hasil belajar yang diperoleh pada siklus I adalah ketuntasan individu dan klasikal. Data tesebut diperoleh melalui tes evaluasi dan kegiatan siswa ketika diskusi atau mengerjakan LKS. Data penilaian proses belajar siswa pada siklus I mencapai 15,4 \% dengan kriteria sangat baik, 38,5\% dengan kriteria baik, dan 46,1 \% dengan criteria cukup. Pada proses diskusi yang dilakukan sudah cukup baik dalam hal kerjasama, keaktifan, keberanian, dan ketepatan dalam menjawab kegiatan yang ada pada LKS dan mereka terlihat enjoy dan antusias dengan menyelesaikan puzzle yang begitu rumit. Akan tetapi masih ada beberapa siswa yang masih tidak mau membantu temannya dalam menyelesaikan LKS. Hal ini langsung direspon oleh peneliti dengan mendekati dan mengajak siswa tersebut untuk mau membantu temannya mengerjakan LKS.

Pada siklus I sebanyak 30,8 \% siswa tuntas dalam pembelajaran dan, 69,2\% siswa tidak tuntas dan nilai rata-rata kelas 69 , 7. Data tersebut menunjukkan bahwa pada siklus I, siswa belum tuntas secara individu maupun klasikal karena nilai rata-rata pada akhir siklus I belum mencapai ketentuan nilai $\geq 75$ dan $\geq 70 \%$.

Pada siklus I banyak siswa yang masih kesulitan dalam mengerjakan soal evaluasi, hal ini bisa dilihat dari hasil evaluasi akhir. Begitu juga terlihat ketika siswa mengerjakan LKS, dimana mereka masih kesulitan dan tidak memahami puzzle yang sudah dibuat oleh peneliti. Padahal puzzle yang dibuat itu sebenarnya merupakan pemahaman konsep dari materi yang sudah dipelajari. Dan diharapkan dengan puzzle ini dapat mempermudah pemahaman siswa terhadap materi.

Ketika guru menampilkan gambar pada slide pun,guru kurang mengeksplorasi pendapat siswa mengenai gambar. Seharusnya guru memberikan kesempatan kepada siswa untuk menyampaikan pendapatnya mengenai gambar yang ditampilkan.

Refleksi merupakan suatu bahan acuan untuk perencanaan selanjutnya, yakni untuk perencanaan siklus II, agar siklus II dapat berjalan lebih baik dari siklus I, sehingga dapat meningkatkatkan hasil belajar siswa dengan menggunakan media puzpipi. Observasi proses belajar mengajar yang dilakukan dan sesudah didiskusikan dengan kedua pengamat diketahui bahwa penulis dalam mengajar sudah bagus, tetapi guru harus memberikan kesempatan siswa untuk mengeksplore pengetahuannya terhadap gambar yang ditampilkan. Media pembelajaran yang digunakan menarik sehingga siswa semangat dalam kegiatan belajar mengajar, tetapi siswa masih bingung dalam penggunaannya. Siswa sudah tertarik mengikuti pelajaran dan menggunakan media puzpipi namun siswa belum berani untuk bertanya dan menjawab pertanyaan sehingga perlu ditingkatkan kembali. Pada siklus I hasil belajar siswa sebesar $30,8 \%$, nilai ketuntasan tersebut masih belum dikatakan tuntas secara klasikal karena belum mencapai ketuntasan $\geq 70 \%$, hal ini disebabkan 
oleh (1) siswa belum terbiasa dengan media puzpipi, selama ini siswa terbiasa dengan pembelajaran secara langsung tanpa menggunakan media. (2) penggunaan media kurang dimanfaatkan dengan baik oleh siswa karena adanya dominasi yang terlalu besar oleh guru. (3) seharusnya dengan diberikannya reward kepada siswa yang berprestasi tentunya juga harus ada punishment jika ada siswa melanggar kesepakatan yang ada (4) dalam berdiskusi, masih ada siswa yang tidak ikut bekerjasama, cenderung hanya 1 sampai 2 siswa saja yang melaksanakan kegiatan yang ada pada LKS.

Hasil observasi oleh dua observer pada siklus ini menunjukkan bahwa semua aktivitas yang dilaksanakan peneliti maupun siswa sudah cukup baik, akan tetapi karena terbatasnya waktu dan konsentrasi siswa menjadi terganggu gara-gara waktu istirahat telah tiba, maka beberapa tahap dalam RPP belum bisa dilaksanakan, yaitu mulai dari pelaporan hasil diskusi sampai tahap evaluasi. Tetapi kegiatan ini dilaksanakan sendiri oleh peneliti dan siswa sesudah istirahat tanpa kehadiran 2 orang observer. Langkahlangkah pembelajaran sesuai dengan RPP yang telah disusun pada tahap perencanaan. Tetapi pengelolaan kelas masih kurang, masih ada beberapa siswa yang kurang aktif dan dominasi guru yang masih terlalu banyak sehingga siswa kadang sampai melamun dan mengantuk. Siswa juga belum aktif dalam diskusi kelompok dan kegiatan pelaporan hasil diskusi. Kekurangan dan kelemahan pada siklus I merupakan dasar dalam rencana untuk perbaikan siklus II. Adapun perbaikan yang dilakukan adalah:

1) Peneliti harus lebih bisa menguasai kelas dengan cara berpindah-pindah posisi untuk bisa menjangkau semua siswa.

2) Mengingatkan siswa yang tidak ikut berdiskusi, agar semua anggota kelompok ikut andil dalam memecahkan masalah dalam LKS.
3) Peneliti melakukan variasi dalam pembelajaran.

4) Memberikan kesempatan kepada siswa untuk memberikan pendapatnya mengenai gambar yang telah di perlihatkan.

5) Memanfaatkan media sebaik mungkin untuk dapat memberikan kesan pada pembelajaran.

6) Menulis hal-hal yang penting untuk bisa diingat atau dicatat siswa.

7) Meminta siswa untuk belajar dirumah, sehingga siswa dapat lebih mudah dalam menyelesaikan LKS dari peneliti maupun soal evaluasi.

\section{Siklus II}

Siklus II dilakukan berdasarkan hasil refleksi pada siklus I untuk memperbaiki kekurangan-kekurangan yang ada saat pelaksanaan tindakan siklus II. Standar Kompetensi dan Kompetensi Dasar yang digunakan sama yaitu tentang jual beli. Siklus ini dilaksanakan satu kali pertemuan pada hari Sabtu tanggal 23 Pebruari 2013.

Observasi tindakan siklus II dilaksanakan pada saat proses pembelajaran. Observasi yang dilaksanakan pada proses pembelajaran siklus II menyangkut kesesuaian antara langkah-langkah pembelajaran dengan Rencana Pelaksanaan Pembelajaran (RPP). Berdasarkan hasil pengamatan diperoleh bahwa peneliti sudah melaksanakan proses pembelajaran sesuai dengan RPP, membuka pelajaran dengan salam dan mem berikan memotivasi siswa. Peneliti telah membagi siswa dalam kelompok belajar. Peneliti telah berkeliling memantau jalannya diskusi kelompok dan membantu kelompok yang mengalami kesulitan. Observasi dilakukan untuk mengetahui aktivitas siswa dan guru selama proses pembelajaran.

Berdasarkan catatan lapangan pada siklus II yang dilaksanakan, diketahui bahwa terdapat 3 siswa yang tidak masuk, 2 siswa karena sakit (Muhammad dan Ninis) serta 1 
siswa karena ijin ada keperluan keluarga (M.Hafid). Jadi jumlah siswa yang mengikuti kegiatan siklus II ini ada 11 siswa dari total 14 siswa yang ada. Situasi saat pembelajaran berlangsung sudah sangat baik dan kondusif dan keaktifan siswapun sudah terlihat, posisi berdiri gurupun sudah berpindah-pindah untuk bisa menguasai kelas dengan baik, sehingga siswa yang bertanya atau berpendapat dapat terakomodasi.

Hasil kegiatan pada siklus II diperoleh data tentang hasil belajar siswa. Data hasil belajar yang diperoleh pada siklus II adalah ketuntasan individu dan klasikal. Data tesebut diperoleh melalui tes evaluasi dan kegiatan siswa ketika diskusi atau mengerjakan LKS.

Pada siklus II sebanyak $81,8 \%$ siswa tuntas dan $18,1 \%$ siswa belum tuntas dan nilai rata-rata kelas 81,4 . Data tersebut menunjukkan bahwa pada siklus II, siswa sudah tuntas secara individu maupun klasikal karena nilai rata-rata pada akhir siklus II sudah mencapai ketentuan nilai $\geq 75$ dan $\geq$ $70 \%$.

Peningkatan hasil belajar siswa pada siklus II ini dibandingkan dengan hasil pada siklus I dibuktikan dengan adanya hasil belajar yang lebih baik. Pada siklus II siswa sudah lebih banyak menyampaikan pendapatnya dan siswa sudah sangat aktif sekali dalam proses pembelajaran maupun diskusi. Dengan adanya media picture and picture dan puzzle yang telah disiapkan oleh peneliti membuktikan adanya peningkatan hasil belajar siswa karena dengan media puzpipi tersebut dapat mempermudah pemahaman siswa dalam materi.

Berdasarkan hasil observasi yang dilakukan peneliti, pada pembelajaran IPS materi Jual Beli dengan menggunakan

me- dia puzpipi pada siklus II terjadi pening- katan aktivitas dan hasil belajar siswa. Ak- tivitas siswa meningkat jika dibandingkan dengan siklus I. Persentase rata-rata aktivi- tas siswa pada siklus I sebesar 30,8 \% dan pada siklus II meningkat menjadi $81,8 \%$. Pada siklus II ini keadaan kelas sudah ter- kontrol dengan baik, siswa sudah banyak diberi kesempatan untuk menyampaikan pendapatnya. Siswa juga aktif dalam kegia- tan pelaporan diskusi.

Pada siklus I banyak siswa yang masih kesulitan dalam menyelesaikan puzzle maupun tes evaluasi karena kurangnya pemahaman pada gambar yang telah ditampilkan sebelumnya, tetapi pada siklus II siswa mengalami peningkatan dalam pemahaman sehingga dapat pula meningkatkan hasil belajar siswa. Pada siklus II ini siswa sudah lebih memahami gambar yang ditampilkan maupun puzzle yang berupa pengerjaan kuis secara berkelompok. Karena ditemukan fakta yang demikian dalam aktivitas dan hasil kegiatan siswa, maka peneliti sebagai guru kelas III SD Muhammadiyah 5 Malang merasa sudah tepat untuk mengakhiri siklus ini. Oleh karena itu siklus II pada penelitian ini dihentikan.

\section{Temuan Penelitian}

Data hasil belajar siswa pada siklus I mencapai 30,8 \% dengan kriteria baik, dan $30,8 \%$ dengan kriteria cukup, dan 38,4\% dengan kriteria kurang. Ketidaktuntasan hasil belajar siswa disebabkan karena pada siklus I masih banyak siswa yang kurang memahami konsep yang telah ditampilkan pada media puzpipi tersebut. Akan tetapi didapati dengan adanya media puzpipi yang sudah disiapkan oleh guru, ternyata menimbulkan efek positif yaitu ada beberapa siswa yang biasanya sangat pasif sekali ketika pembelajaran biasa, dengan media ini dia kelihatan antusias sekali (M.Iqbal). Begitu pula beberapa siswa yang sudah berani memberikan komentar dan mau bekerja sama dengan baik dalam diskusi kelompok (Muhammad dan Fauzan). Hal ini membuktikan bahwa dengan media puzpipi bias meningkatkan proses pembelajaran yang diha- 
rapkan juga dapat meningkatkan hasil belajar siswa.

Pada siklus II hasil belajar siswa meningkat yakni sebanyak 45,5\% siswa tuntas dengan kriteria sangat baik, 36,4\% siswa tuntas dengan kriteria baik dan nilai ratarata kelas 81,4 . Peningkatan hasil belajar siswa terlihat dari hasil evaluasi akhir siswa maupun selama proses pembelajaran. Siswa sudah banyak yang aktif mengikuti pembelajaran mulai dari awal sampai akhir. Dan berdasarkan wawancara dengan beberapa siswa dapat dibuktikan dengan media yang sudah dipakai pada hari ini ternyata siswa tidak merasakan bahwa mereka telah mengikuti pembelajaran akan tetapi yang mereka rasakan adalah mereka bermain dengan game/kuis/puzzle yang sudah disediakan oleh guru. Mereka juga sangat senang sekali dengan adanya tepuk pasar maupun nyanyian yang sudah diciptakan sendiri oleh guru untuk membantu pemahaman siswa dalam memahami konsep tentang materi yang mereka pelajari.

Aktivitas siswa selama proses pembelajaran pada siklus I rata-rata $15,4 \%$ dengan kriteria sangat baik, 38,5\% dengan kriteria baik, dan 46,1 dengan kriteia cukup. Berdasarkan pengamatan data tersebut diperoleh karena selama proses pembelajaran siswa belum diberikan kesempatan secara penuh untuk menyampaikan pendapatnya, dan pada proses pembelajaran penggunaan media puzpipi belum bisa dimanfaatkan secara maksimal oleh siswa dalam pembelajaran. Namun pada siklus II siswa sudah mengalami peningkatan proses penerapan media puzpipi sudah cukup baik yakni rata-rata sebesar 9,0\% dengan kriteria sangat baik dan sebesar 45,5\% dengan kriteria baik. Hal ini ditunjukkan siswa sudah berani untuk mengeluarkan idenya terlihat saat melihat gambar yang ditampilkan maupun menyelesaikan puzzle yang sudah disediakan.

Hasil belajar siswa pada siklus I sebanyak $30,8 \%$ siswa tuntas dengan criteria ba$\mathrm{ik}, 30,8 \%$ siswa dengan kriteria cukup dan sebesar $38,4 \%$ siswa dengan criteria kurang. Hasil belajar siswa pada siklus II meningkat yakni sebanyak 45,5\% siwa atau 5 siswa tuntas dengan kriteria sangat baik, 36, $4 \%$ siswa tuntas dengan kriteria baik atau 4 siswa dan sebesar $18,1 \%$ siswa dengan kriteria cukup atau 2 siswa.

Oleh karena pada siklus II siswa sudah tuntas secara individu maupun klasikal dan nilai rata-rata pada akhir siklus II sudah mencapai ketentuan nilai $\geq 75$ dan $\geq 70 \%$ maka dengan demikian penelitian ini dihentikan pada siklus II ini. Dan penelitian ini dinyatakan berhasil karena sudah memenuhi kriteria yang telah ditentukan sebelumnya.

\section{Kesimpulan}

Berdasarkan pembahasan hasil penelitian pada siklus I dan siklus II dapat disimpulkan bahwa:

Pelaksanaan pembelajaran IPS materi jual beli siswa kelas III SD Muhammadiyah 5 Malang dapat dilaksanakan dengan efektif dalam 2 siklus, setiap siklus terdiri dari 1 kali pertemuan. Langkah-langkah pembelajaran pada RPP sesuai dengan model Picture and Picture dan Media "Puzpipi". Dalam pelaksanaan pembelajaran penggunaan media puzpipi, peneliti menggunakan variasi dalam hal proses pem belajaran dan pembagian kelompok dari per temuan sebelumnya kepertemuan selanjutnya dengan membagi kelompok secara acak dan heterogen supaya siswa lebih aktif dan bisa bekerja sama dengan baik dalam mengerjakan tugas kelompoknya. Selain itu guru juga menguasai kelas dengan baik dengan cara memperhatikan setiap pendapat siswa maupun menanggapi siswa yang bertanya atau menemui kesulitan. Media yang digunakan baik yang berupa puzzle maupun picture/gambar dapat membantu siswa dalam memahami materi maupun menggali pengetahuan siswa. 
Penggunaan media puzpipi (puzzle dan picture and picture) dapat meningkatkan hasil belajar siswa kelas III SD $\mathrm{Mu}-$ hammadiyah 5 Malang. Peningkatan hasil belajar siswa dari siklus I ke siklus II meningkat. Siklus I sebesar 61,6 dan siklus II sebesar 81,9. Ketuntasan klasikal juga mengalami peningkatan yaitu pada siklus I sebesar $69,7 \%$ sedangkan pada siklus II sebesar $81,4 \%$.

\section{Saran}

Berdasarkan kesimpulan diatas maka diajukan beberapa saran yang perlu dipertimbangkan yaitu:

Bagi guru kelas SD Muhammadiyah 5 Malang disarankan untuk menggunakan media puzpipi (puzzle dan picture and picture) sebagai salah satu alternatif penggunaan media di kelas, agar dapat meningkatkan hasil belajar siswa.

Bagi siswa disarankan dengan digunakannya media puzpipi dapat meningkatkan peran aktif siswa selama proses pembelajaran dan meningkatkan hasil belajar siswa.

Bagi sekolah disarankan untuk meningkatkan kualitas pembelajaran IPS dengan menerapkan metode pembelajaran dan media yang lebih tepat dan bervariasi.

Bagi peneliti selanjutnya diharapkan dapat melakukan penelitian sejenis dalam rangka memperbaiki hasil belajar siswa dengan menggunakan media puzpipi pada subjek penelitian yang berbeda.

\section{Daftar Pustaka}

Abdussakir, 2003. Pengembangan Paket Pembelajaran Berbantuan Komputer Materi Irisan Dimensi Tiga. Tesis tidak diterbitkan. Malang: PPS UM.

Depdiknas, 2006. Kurikulum Tingkat Satuan Pendidikan (KTSP) Mata Pelaja- ran Matematika untuk SD/MI. Jakarta: Depdiknas

Hudojo, H. (1998). Pembelajaran Matematika Menurut Pandangan Konstruktivis. Makalah ini disajikan pada Seminar Nasional Pendidikan Matematika, PPs IKIP Malang, 4 April 1998

Hudojo, H. (2005). Kapita Selekta Pembelajaran Matematika. Malang: Universitas Negeri Malang (UM Press).

Madja, M.S.. 1992. Perancangan dan Implementasi Perangkat Ajar Geometri SMTA. Tesis tidak diterbitkan. Jakarta: PPS UI.

Moloeng, L.J.. 2000. Metode Penelitian Kualitatif. Bandung: Remaja Rosda Karya.

NCTM, 2000. Principles and Standards for School Mathematics. Reston, Virginia : The National Council of Teachers of Mathematics, Inc.

Ratumanan, T.G.. 2002. Belajar dan Pembelajaran. Surabaya: Unesa University Press. 